\title{
Leptomeningeal Dissemination of Pilocytic Astrocytoma in a 17-Year-Old Boy
}

\section{Yaşında bir Erkekte Pilositik Astrositomun Leptomeningeal Yayılımı}

\author{
Ali Babaei JANDAGHI ${ }^{1}$, Elham BIDABADI ${ }^{2}$, Seyed Mohammad SEYED SAADAT ${ }^{3}$, Babak ALIJANI ${ }^{4}$, \\ Saeid DALIRI ${ }^{1}$, Zoheir REYHANIAN ${ }^{4}$, Mehryar MASHOUF \\ ${ }^{1}$ Guilan University of Medical Sciences, Poursina Hospital, Department of Radiology, Rasht, Iran \\ ${ }^{2}$ Guilan University of Medical Sciences, Department of Pediatric Neurology, Rasht, Iran \\ ${ }^{3}$ Guilan University of Medical Sciences, Rasht, Iran \\ ${ }^{4}$ Guilan University of Medical Sciences, Poursina Hospital, Department of Neurosurgery, Rasht, Iran \\ ${ }_{5}^{5}$ Arya Hospital, Department of Neurosurgery, Rasht, Iran
}

Corresponding Author: Seyed Mohammad SEYED SAADAT / E-mail: arman.saadat@gmail.com

\begin{abstract}
Pilocytic astrocytoma with leptomeningeal dissemination is a rare phenomenon and can be associated with obstructive hydrocephalus and an unfavorable prognosis. Herein, we report a seventeen-year-old boy with a history of ventriculo-peritoneal shunt insertion due to severe hydrocephalus who presented with progressive headache and vomiting together with ocular and cerebellar signs and symptoms. Neuroimaging confirmed the presence of multiple intracranial masses in the cerebellum and thalamus. Intracranial dissemination of tumor to the the leptomeninges was seen during neuroendoscopy. Simultaneous biopsy and endoscopic third ventriculostomy were performed and the diagnosis of low-grade pilocytic astrocytoma with leptomeningeal dissemination was made by histological examination. The patient underwent chemotherapy in combination with radiotherapy to reduce the risk of reoccurrence of the primary tumor and was followed for one year.
\end{abstract}

KEYWORDS: Pilocytic astrocytoma, Leptomeningeal dissemination, Hydrocephalus, Neuroendoscopy

\section{öz}

Leptomeningeal yayılımlı pilositik astrositom nadir bir olaydır ve obstrüktif hidrosefali ve kötü prognozla ilişkili olabilir. Burada şiddetli hidrosefali nedeniyle ventriküloperitoneal şant uygulama öyküsü olan ve oküler ve serebellar bulgu ve belirtilerle birlikte ilerleyici başağrısı ve kusmayla gelen 17 yaşında bir erkek olgu bildiriyoruz. Nörogörüntüleme, serebellum ve talamusta çok sayıda intrakraniyal kitle varlığını doğruladı. Nöroendoskopi sırasında tümörün leptomeninkslere intrakraniyal olarak yayıldığı görüldü. Aynı anda biyopsi ve endoskopik üçüncü ventrikülostomi yapıldı ve histolojik incelemeyle leptomeningeal yayılımlı düşük dereceli pilositik astrositom tanısı kondu. Hastaya primer tümörün tekrar oluşması riskini azaltmak üzere radyoterapiyle kombinasyon halinde kemoterapi verildi ve bir yıl takip yapıldı.

ANAHTAR SÖZCÜKLER: Pilositik astrositom, Leptomeningeal yayılım, Hidrosefali, Nöroendoskopi

\section{INTRODUCTION}

Pilocytic Astrocytoma (PA) is a low-grade tumor, occurring predominantly in pediatric patients and located in various parts of the CNS with a predilection for the cerebellum, thalamus, third ventricle, optic tracts, brain stem, and medial temporal lobe $(3,6)$. Although PA is associated with an excellent outcome and long-term survival, dissemination of PA to leptomeninges, a rare phenomenon with limited cases published in the medical literature, has been linked with an unfavorable prognosis $(6,10)$. Extension of PA to the third ventricles is uncommon but associated with obstructive hydrocephalus requiring an invasive procedure to divert the cerebrospinal fluid (CSF) flow (8).

To date, only 59 patients of PA with leptomeningeal dissemination have been reported in the literature. We reported here a case of hydrocephalus caused by PA with leptomeningeal dissemination.

\section{CASE REPORT}

\section{History}

A 17-year-old boy presented to our neurosurgery center with severe neurological impairment. Eight month ago, he presented to other center with gradual onset of headache, progressive vomiting and neck stiffness as well as a two week history of gait disturbance and vertigo. Brain CT scan and MRI showed severe hydrocephalus without evidence of mass lesion or any abnormal enhancement; therefore, the patient underwent ventriculo-peritoneal shunt placement. His symptoms improved and he was asymptomatic until a week ago, when his symptoms were exacerbated and experienced progressive blurred vision, several episodes of seizure and sudden transient unilateral visual loss. His past medical history was unremarkable. 
On physical examination, his consciousness was impaired $(G C S=13)$ and his vital signs were normal. Obvious meningismus and cerebellar signs were present on his neurological examination. He had mild ataxia and tandem gait and Romberg tests were impaired. The visual acuity measurement revealed only light perception in both eyes. No other neurological deficits were noted.

Laboratory tests were within the normal limit. CT scans demonstrated hydrocephalus and multiple hypodense mass lesions in the third ventricle and basal cisterns. MRI showed multiple masses in the posterior fossa. These masses were hypointense on T1W and hyperintense on T2W Images. Leptomeningeal thickening, hydrocephalus as well as tumoral implants in sylvian fissures and basal cisterns were also noted. Minimal enhancement was detected in some lesions after intravenous administration of gadolinium (Figure 1A-F).
ETV was performed to treat hydrocephalus and obtain biopsy. Ventricular CSF culture was negative and cytological findings were positive for malignant cells. Histological examination showed neoplastic tissue composed of low cellular proliferated astrocytes with bipolar cytoplasmic process, arranged in a microcystic and vague fascicular array that confirmed the diagnosis of PA with leptomeningeal dissemination (Figure 2). The patient then received 10 single courses of chemotherapy in combination with radiation with a dose of (5400 cGy) to reduce the risk of reoccurrence of the primary tumor.

The patient was discharged after 2 months of hospitalization with minimal neurological deficit. The patient's condition gradually improved. He was followed-up at 3 and 6 months and a year after radiation. His visual acuity gradually changed from light perception to counting fingers. There was no evidence of disease progression on imaging.

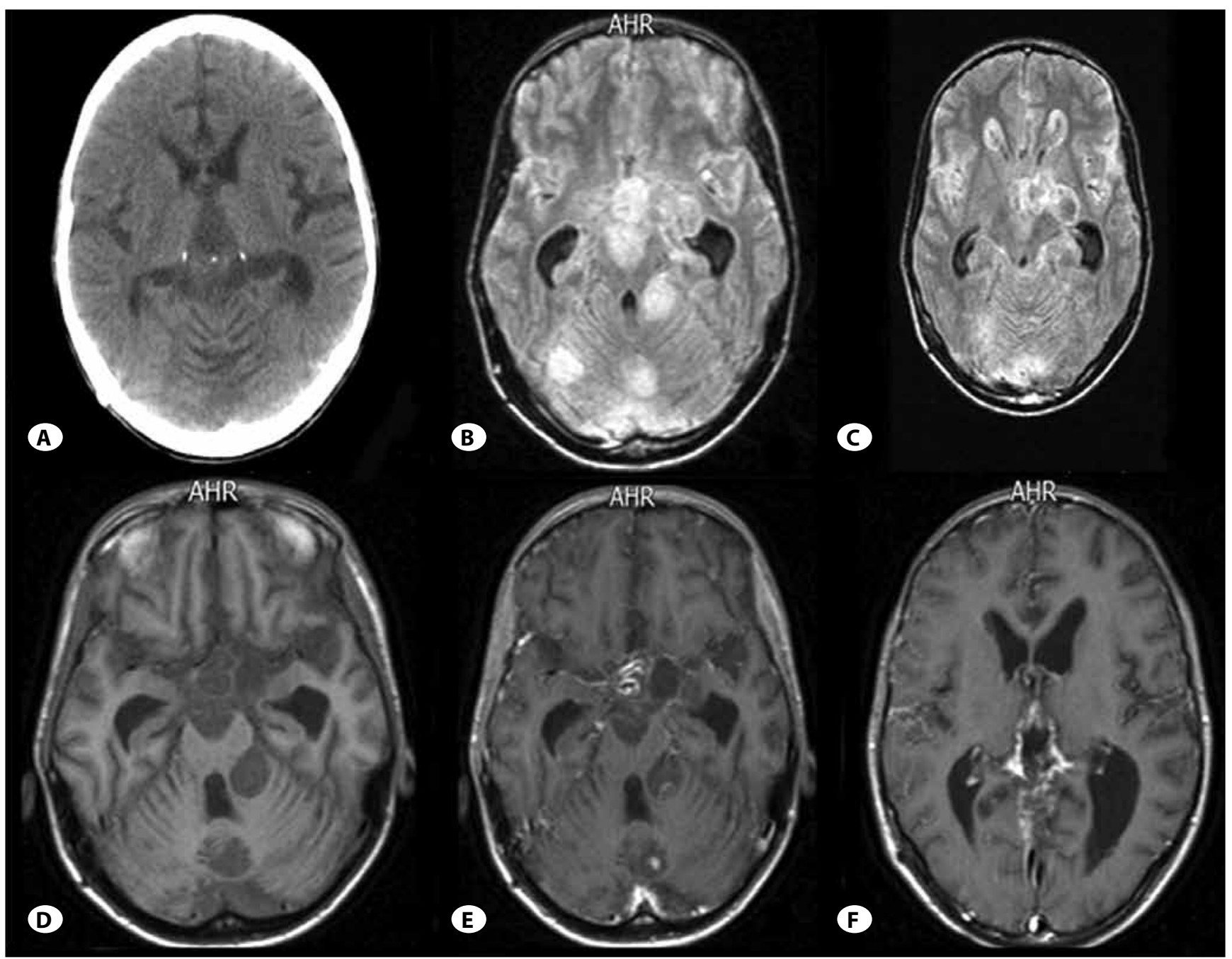

Figure 1: A) Plain CT scan shows hydrocephalus as well as hypodense lesions in ventricular spaces, basal cisterns, atrium and lateral ventricles. B) Fluid attenuated inversion recovery (FLAIR) reveals multiple hyperintense lesions. C) Multiple masses adjacent to ventricular region and sub-ependymal dissemination of tumor to the frontal horns. D) T1-weighted images show dilatation of third ventricles and multiple hypointense and heterogeneous lesion in the posterior and middle fossa with multiple tumoral implants in the ventricles and basal cisterns. E, F) Axial T1-weighted MR image after contrast administration shows minimal enhancement of intraparanchymal and diffuse subarachnoid enhancement. 


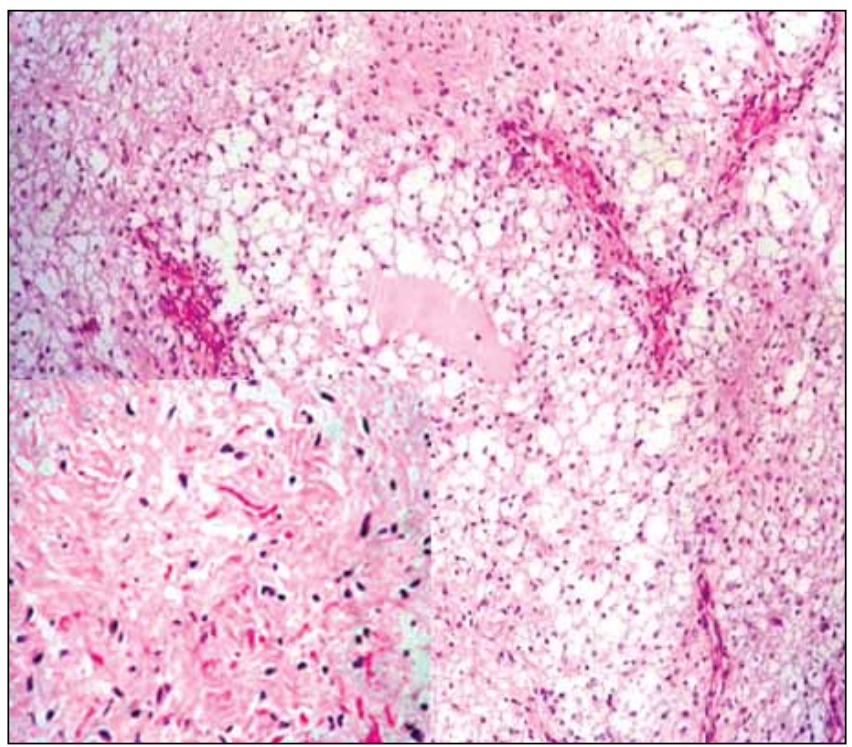

Figure 2: Histopathology of pilocytic astrocytoma demonstrates low cellular proliferated cells with bipolar cytoplasmic processes. Stroma is fibrillar with some small microcystic changes [Hematoxylin and eosin stain $(\mathrm{H} \& \mathrm{E}) \times 100]$ ]. Insert: The cellularity is low, mitotic activity or necrosis is not seen. The vessels are inconspicuous (H\&E x 400).

\section{DISCUSSION}

Very few cases of PA with leptomeningeal dissemination have been described in the literature. The disease predominantly affects children and young adults in their early decades of life, with a predilection for males (10). Mazloom et al. concluded from literature review that hypothalamic-chiasmatic region, cerebellum and third ventricle are the most common locations of primitive tumors and overall 5-year survival rate of patients is $55.5 \%$. He also noted high efficacy of both radiotherapy and chemotherapy in these patients (10). Bilginer et al. revealed that $77.5 \%$ of patient with astrocytoma have concomitant hydrocephalus, and proposed hydrocephalus as the main cause of disease-related symptoms (4). PA is usually associated with a favorable prognosis and 5-year survival rate of about $95 \%$ in those where the primitive lesions were initially removed, but rarely it can show grim presentation by malignant transformation, reoccurrence, invasion and metastatic spread $(4-6,12)$.

Leptomeningeal dissemination of brain tumors is a rare phenomenon and occurs more commonly in ependymomas, germ cell tumors, medulloblastoma, and high-grade gliomas (6). leptomeningeal dissemination of low-grade astrocytoma, particularly those diagnosed at presentation, has rarely been reported in the medical literature with fewer than 60 cases $(3,6)$. The exact incidence still remains unclear $(6,12)$. Previous studies have demonstrated that leptomeningeal dissemination occurs in approximately 4 to up to $12 \%$ of patients with low grade gliomas or low grade astrocytomas $(9,11)$. It seems that with the growing use of MRI as a routine investigative tool for the diagnosis of brain tumors will increase the number of these patients are being identified (5).

The exact mechanism and risk factors of leptomeningeal dissemination of low-grade PA is unknown $(6,12)$. Recent studies cite intracranial surgical intervention (i.e. shunt insertion and/or partial tumor excision), and anatomical proximity of the primary tumor to subarachnoid spaces, CSF cisterns or ventricles as the most common risk factors $(5,12)$. This phenomenon could also be part of the natural course of tumor progression if left untreated or could originate from unknown biological factors such as degree of adhesiveness, capacity to invade the leptomeninges, and metabolic or antigenic factors $(5,6)$. In our patient, it is likely that the history of VP shunt insertion is responsible for leptomeningeal dissemination. Data regarding the outcome of PA with leptomeningeal dissemination is limited $(6,10)$. In most previous studies, the outcome of these patients was associated with a better prognosis than those suffered from other brain tumors such as high grade gliomas (10). However, they seem to have a worse prognosis than patients with totally excised primitive tumor or localized reoccurrence (6).

In most previous reported cases, placement of VP shunts was performed for the treatment of hydrocephalus by using classic surgical methods, whereas ETV can prevent shunt-related complications such as systemic and/or intraperitoneal tumor seeding, which may happen following VP shunt insertion (2).

Since leptomeningeal dissemination of PA is a very rare entity, the most ideal treatment of the disease is still debated $(5,12)$. Recent studies have shown that total resection of the primitive tumor, if possible, is the treatment of choice (5). Previous studies have also demonstrated the beneficial effects of both chemotherapy and radiotherapy, alone and in combination with each other, in the treatment of leptomeningeal dissemination $(6,10)$. However, controversy continues about the best strategies for the management of these patients. Our case underwent both chemotherapy and radiotherapy. Some of his early symptoms improved and he did not experienced adverse effects during one year follow up.

\section{REFERENCES}

1. Ahn ES, Goumnerova L: Endoscopic biopsy of brain tumors in children: Diagnostic success and utility in guiding treatment strategies. J Neurosurg Pediatrics 5:255-262, 2010

2. Behari $S$, Jaiswal $S$, Nair $P$, Garg $P$, Jaiswal AK: Tumors of the posterior third ventricular region in pediatric patients: The Indian perspective and a review of literature. J Pediatr Neurosci 6 Suppl 1:56-71, 2011

3. Bian SX, McAleer MF, Vats TS, Mahajan A, Grosshans DR: Pilocytic astrocytoma with leptomeningeal dissemination. Childs Nerv Syst 29 (3):441-450, 2013

4. Bilginer B, Narin F, Oguz KK, Uzun S, Soylemezoglu F, Akalan $\mathrm{N}$ : Benign cerebellar pilocytic astrocytomas in children. Turk Neurosurg 21:22-26, 2011 
5. Buschmann U, Gers B, Hildebrandt G: Pilocytic astrocytomas with leptomeningeal dissemination: Biological behavior, clinical course, and therapeutical options. Childs Nerv Syst 19:298-304, 2003

6. Figueiredo EG, Matushita H, Machado AG, Plese JP, Rosemberg $\mathrm{S}$, Marino R Jr: Leptomeningeal dissemination of pilocytic astrocytoma at diagnosis in childhood: Two cases report. Arq Neuropsiquiatr 61:842-847, 2003

7. Komotar RJ, Burger PC, Carson BS, Brem H, Olivi A, Goldthwaite $P$, Tihan T: Pilocytic and pilomyxoid hypothalamic/chiasmatic astrocytomas. Neurosurgery 54:72-80, 2004

8. Kumar SVR, Mohanty A, Santosh V, Satish S, Devi BI, Praharaj SS, Kolluri SVR: Endoscopic options in management of posterior third ventricular tumors. Childs Nerv Syst 23: 1135-1145, 2007
9. Mamelak AN, Prados MD, Obana WG, Cogen PH, Edwards MSB: Treatment options and prognosis for multicentric juvenile pilocytic astrocytoma. J Neurosurg 81:24-30, 1994

10. Mazloom A, Hodges JC, Teh BS, Chintagumpala M, Paulino AC: Outcome of patients with pilocytic astrocytoma and leptomeningeal dissemination. Int J Radiation Oncol Biol Phys 84:350-354, 2012

11. Perilongo G, Garrè ML, Giangaspero F: Low-grade gliomas and leptomeningeal dissemination: A poorly understood phenomenon. Childs Nerv Syst 19:197-203, 2003

12. Rondinelli PIP, Osório CAM, Cohen MP, Novaes PERS: Unusual dissemination patterns of low-grade astrocytomas in childhood. Arq Neuropsiquiatr 66:45-49, 2008 